\title{
Metaphors of organ donation, social representations of the body and the opt-out system
}

\author{
Mary Anne Lauri* \\ University of Malta, Msida, Malta
}

\begin{abstract}
Organ donation is the only available treatment for end-stage failure of organs such as liver, lung, and heart and therefore increasing the number of organ donors is a priority for most countries. One measure that could be taken by a country to increase the number of organ transplants is to introduce the opt-out system of organ donation. Public opinion is divided on this issue and policy makers need to tread with caution before introducing legislation. This paper proposes that understanding the social representations the public has of organ donation is important in taking the right policy decisions. We propose here that an in-depth study of the views held by people on the issue is essential in this regard and that this can best be done by investigating the metaphors people use to describe organ donation, interpreted within the theory of social representation. In this study, the social representations of organ donation were investigated through five focus groups with 57 participants living in Malta. Analysis of the transcriptions of these focus groups yielded pertinent issues related to organ donation. Moreover, metaphors of organ donations and how these were related to social representations of the body and attitudes towards the opt-out system are discussed. It is being suggested that these findings could be of relevance to the present discussion on the opt-out system in the UK and in other countries.
\end{abstract}

In Britain, there are more than 8,000 patients waiting for an organ transplant and more than 1,000 a year die without receiving the organ that could save their lives (EU Consultation Document on Organ donation, 2006). Organ transplantation is now the most cost effective treatment for end-stage renal failure. It is also the only available treatment for end-stage failure of organs such as liver, lung and heart (EU Consultation Document on Organ Donation, 2006).

On January 13, 2008, several news agencies discussed the controversy stirred up by what the British Prime Minister Gordon Brown wrote in The Telegraph. The Prime Minister wrote in favour of the opt-out system of organ donation and said that parliament was considering legislation to enable doctors to remove organs from dead

\footnotetext{
* Correspondence should be addressed to Dr Mary Anne Lauri, Department of Psychology, University of Malta, Msida MSD 2080, Malta (e-mail: mary-anne.lauri@um.edu.mt).
} 
patients without permission of their next of kin. This policy of 'opting-out' or 'presumed consent' means that, unless people opted out of the donor register, hospitals would be allowed to take their organs for transplants without the need of the relatives' consent (Brown, 2008). There was a strong reaction to his statement. On one side, the lobby groups for patients' rights claimed that the state does not own the body of a dead person and the decision whether or not to donate one's organs after death should be a private decision. On the other hand, England's chief medical officer, Sir Liam Donaldson as well as The British Medical Association supported the opt-out system. Donaldson said that the current uncoordinated practice vis-à-vis organ transplantation was poor, with many distressed relatives rejecting requests to donate organs of their dead relatives (Wintor, 2008).

This difference in opinion on whether or not to introduce the opt-out system exists among the general public as well as the professionals and authorities. A quick look at the on-line comments posted on January 14 by readers of The Times (Webster, 2008) shows that some readers did believe that in the context of long waiting lists for organ transplants, legislation should intervene in order to save the lives of people waiting for a transplant. However, many of the readers' letters showed how talk about the opt-out system can revive the fears surrounding organ donation. Readers wrote about 'mutilated', 'violated', and 'incomplete' bodies. One reader exclaimed 'Over my dead body', describing the system as 'corpse robbing' and used the terms 'evil', 'ungodly', and 'repugnant'.

But perhaps of more concern are the objections raised by those who, in principle, are in favour of organ donation. One such person wrote that 'If people want to give the gift of life, that is their right, but it must be something that is voluntary'. Another insisted that organ donation should be an 'active choice' and another wrote that, instead of forcing the issue through legislation, the Prime Minister should be 'educating people and using a campaign to donate organs' (Webster, 2008).

The e-debate on The Telegraph raged even more widely. By April 18, Mr Brown's article had provoked 693 on-line postings by readers of The Telegraph, ranging from complete agreement with the introduction of the opt-out system to threats by donor card holders that they would tear up their card if the system were to be introduced.

A similar public discussion on organ donation and the opt-out system took place in Malta when a national communication campaign was launched to create greater awareness about organ donation in 1996. Several issues emerged from the research conducted to inform the campaign and the evaluative research carried out to evaluate its short-term and long-term effects. These issues are reported in detail in Lauri (2001, 2008). This paper will focus on one aspect of these findings which has greatest relevance to the situation in the UK today, that is, the reasons why there are such different positions among the public regarding the introduction of the opt-out system. It will be argued that one's opinion on whether the legislator has a right to introduce 'presumed consent' depends on various factors, two major ones being: (i) how one looks upon organ donation and (ii) how one looks upon one's own body.

In order to understand people's views on a complex issue like organ donation, the researchers involved in the design of the campaign decided that is was important to tap into the roots of the social representations people had on organ donation. The theory of social representations was used to inform the design of the campaign. This is because this theory helps the researcher understand how people make sense of such a complex issue by giving their own lay interpretation of the views and opinions directed at them by experts such as medical practitioners, political leaders, and the church and how different ways of elaborating these views lead to different public opinions. The decision 
to have the theory of social representations as the main theoretical underpinning of the campaign could arguably account for its success. The main slogan of the campaign made use of the actual words which participants used in the focus groups to describe organ donation - 'Give a new life'. This slogan was consistently used throughout the campaign in all radio, television, and print media.

One indication of the success of the campaign was the number of organ transplants carried out. In the year before the campaign there were 12 transplants. In the year following the campaign, the number of transplants increased to 32 and in the next year to 30. It is of course, impossible to claim that the increase in the number of transplanted organs was solely the result of the campaign but it is reasonable to suppose that the campaign was a main instigator of the increase in the number of organ transplants.

In the next section, we shall describe some aspects of the theory of social representations which are most relevant to this research. In the following sections, we shall use this theory to analyse the focus groups carried out before the campaign. Finally, we shall discuss how this experience in Malta might be relevant to the present public discussion in the UK.

\section{Social representations and metaphors}

In his book La psychoanalyse, son image et son public published in 1961, Moscovici described what psychoanalyses meant to French people (Moscovici, 1961). He described how psychoanalytic concepts, normally discussed in the 'reified universe' of psychologists and psychiatrists, proliferated among different groups of French society and transformed themselves into lay theories which formed the bulwark of everyday discourse and common sense (Moscovici, 1961). This seminal work was the beginning of an area of study which has today become one of the most researched areas in social psychology and one of the most important tools to study public opinion.

Social representations are not simply opinions or attitudes. They are lay theories about issues, concepts, or events, which feature in everyday conversations. They are systems of values, ideas, and practices which enable people to understand and make sense of various aspects of their material and social world and enable them to master this world (Moscovici, 1973, p. xiii, 'Foreward' to Herzlich). Ultimately, 'the purpose of all representations is to make something unfamiliar, or unfamiliarity itself, familiar' (Moscovici, 1984, p. 24). Jovchelovitch (2007) points out that the work of representation 'relates to the construction of worldviews, to the establishment of systems of everyday knowledge that not only seek to propose a framework to guide communication . . . but also actively express projects and identities of social actors and the interrelations between them' (p. 12).

The notion of social representations is therefore of paramount importance to policy makers who need public support for their reforms such as that being suggested regarding the donation of organs. The facts as presented to the policy maker by the experts in the field, Moscovici's 'reified universe', might very well indicate that it is reasonable to expect that the reform should meet with wide public support. But the lay theories on which public opinion is based could be quite different from those held by the experts.

But how are these 'worldviews' constructed? How is the unfamiliar made familiar? Moscovici (1984) posits the two closely linked processes of 'anchoring' and 'objectification' as the means through which a novel concept is introduced into everyday discourse. These processes assimilate and accommodate the new concept 'to already familiar concepts that are socially shared and culturally available' (Augoustinos \& 
Penny, 2001, p. 4.4). Anchoring is the 'assimilation of unfamiliar phenomenon to preexisting representations, thereby "converting" an external object into a mental content' (Wagner, Elejabarrietta, \& Lahnsteiner, 1995, p. 672).

One key element often involved in the process of objectification is the metaphor. According to Wagner and Hayes (2005), social representations are related to thinking in terms of images, icons, and metaphors. 'The concrete form that content-rational knowledge and social representations adopts in the heads of its bearers can best be compared with images and metaphors' (p. 170). Wagner et al. (1995) describe images, metaphors, and symbols as 'objectification "devices", i.e. "tools" by which the end of understanding through objectification is achieved' (p. 673).

So how are metaphors in the context of the theory of social representations defined? To answer this question we shall mostly follow the work by Wagner and Hayes (2005) (see also Wagner et al., 1995). Essentially a metaphor is a mapping between a source domain and a target domain. The source domain is the familiar domain, close to personal experience and easily comprehensible. The target domain is the unfamiliar domain, farther away from personal experience, and more difficult to understand. The mapping is an association between elements of the source domain and the target domain. But such a mapping is not simply the attaching of familiar labels to unfamiliar concepts. The mapping 'defines a structural correlation' between the source and the target domain and 'establishes relevant structural similarities between target and source' (Wagner \& Hayes, 2005, p. 171). It projects relationships between elements in the familiar source domain into analogous relationships between elements in the target domain. We shall use the term 'homomorphism' to describe a mapping with this property. In Wagner et al. (1995), for example, this homomorphic character of metaphors is very well illustrated. In this paper, subjects compared the sperm and the ovum in process of fertilization with sexual and sex-role behaviour where the roles of men and women were projected upon sperms and ovum, respectively, implying that sperms are seen as more active, harder, stronger, and more dominant than the ovum.

We shall argue in a later section how the metaphors identified from the analysis of our focus groups have this homomorphic property. This characteristic of metaphors can help the researcher understand how and why people have different views on the optout system and how these can be addressed to effect change and reduce resistance to changes in policy.

As Wagner and Hayes (2005) point out, the mapping which constitutes the metaphor 'is the result of a constructive effort in communication and discourse' (p. 171). Metaphors and social representations are societal creations. One way of discovering these metaphors is by listening to people talking in informal settings. These informal conversations guide the researcher to discover the lay theories which the public have and use to argue and form opinions. One method which simulates this process in a relatively controlled setting is the focus group. The focus group is the thinking society in miniature (Farr, Trutkowski, \& Holzl, 1996) and therefore it is ideal for bringing out the social representations held by participants on complex issues such as organ donation.

\section{Methodology}

Before designing the campaign it was important to study public opinion, attitudes and representations the Maltese people had of organ donation. Three data collecting tools were used. These were surveys, interviews, and focus groups. One survey, the 
interviews and the focus groups were carried out before the campaign, in order to inform its design and conduct. The survey was also repeated three times after the campaign over a 10-year period in order to assess its short-term and long-term effectiveness. In this paper, we will consider only the data elicited in the focus group discussions. For a more detailed discussion of the findings from the interviews and the surveys one can refer to Lauri $(2001,2006)$ and Lauri and Lauri (2005).

Five focus group discussions were organized with a volunteer sample of 57 persons recruited from 14 different towns and villages in Malta, an island in the Mediterranean with a population of about 400,000 people. The participants were recruited from supermarkets in different geographic regions of Malta. They were evenly distributed between women and men, between young and middle-aged persons and had different levels of education. Sixteen participants dropped out and did not attend the focus groups. Only two participants were donor card holders.

Focus group discussions lasted between 60 and $90 \mathrm{~min}$ and were recorded with the permission of the participants. Each recorded session was transcribed fully. These transcriptions were the primary texts for the subsequent analysis. Appendix gives information about the composition of the focus groups.

\section{A first analysis of the data: Categories, themes, and keywords}

The transcripts of the focus group discussions were analysed using ATLAS/ti. The analysis of the focus group discussions yielded themes which were grouped under the headings (i) normative context, (ii) decision making, (iii) death and body image, (iv) ethical issues, and (iv) medical issues. These categories and the associated themes and keywords are shown in Table 1.

We shall briefly discuss these five categories which will provide the insight for extracting the metaphors and representations presented in the next section.

\section{(i) Normative context}

The Catholic Church is a powerful influence in Malta, and this was reflected by the importance many participants gave to what the Church says when expressing normative views on organ donation. Many of the reasons which participants gave for wanting to donate organs were related to altruism. As in the findings of Morgan and Miller (2002), many felt that organ donation is good because it helps someone live. Organ donation was also seen as a concrete way of practising one's religion which places a lot of emphasis on helping others. It was looked upon as an act of altruism based on the commandment 'love your neighbour as yourself'.

Whereas some considered organ donation as a moral duty, something that all people should do, others looked upon it as an act of charity, something, over and above what is expected of a person. One participant said that saving a person's life is a chance to do something heroic. Another reason given for donating one's organs was that of the recycling of resources. A few participants felt that it is a waste to let good organs rot away when they can be used to help other people lead a normal life. These images are discussed in more detail in the next section.

\section{(ii) Decision making}

Many participants saw the signing of the donor card as the result of a decision taken freely in one's own time, sometimes spontaneously and at other times after deliberate 


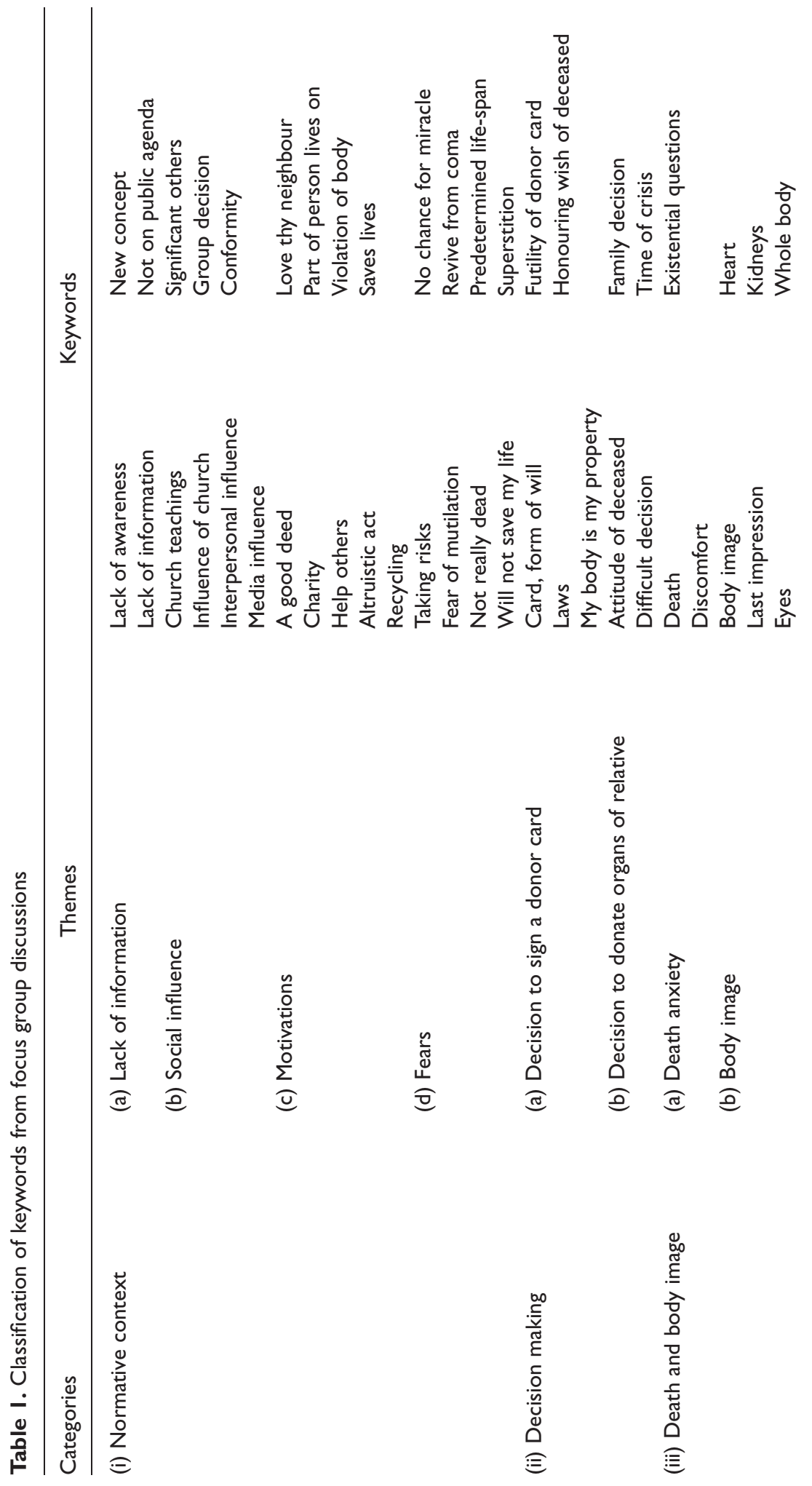




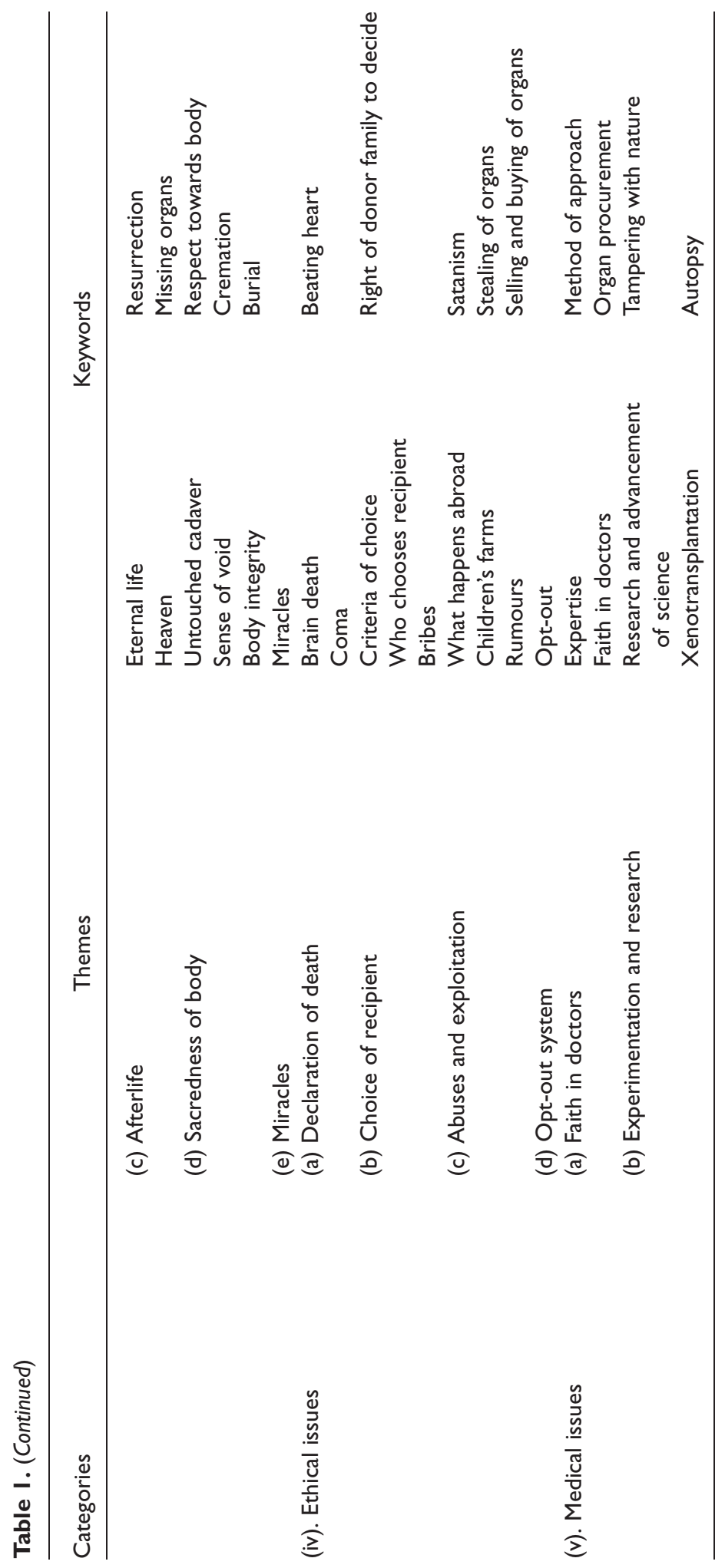


thought. It is a pledge which, at the time of signing, seems distant and improbable. On the other hand, the decision to donate the organs of a close family member occurs at a time of crisis when the family is still trying to come to terms with the death of a loved one. It is a situation laden with emotions. Similar to the findings of Calvo, Blanca, and de Frutos (2002) and Perkins (1987), participants said that knowing the wishes of the deceased about organ donation would help them in taking a decision.

Connected with this issue, and very relevant to the question of the opt-out system, is the discussion of who owns the cadaver and consequently who should decide about whether or not to donate organs. The belief in the individual's right of choice was virtually shared by everyone, even by those who were in favour of organ donation.

\section{(iii) Death and body image}

Different participants had different conceptions of their body. Some saw their body in the light of the teaching of the Catholic Church as belonging to God and that it was theirs 'on loan'. Others saw the body more as a treasured possession, something dear that belonged to them. There were other participants who made no distinction between the physical, the psychological, and the spiritual aspects of the body. Similar findings were found by Sanner (1994).

The question of what would happen to the organs in the afterlife was a frequent theme of discussion. Since the Church teaches resurrection of the body as well as of the soul, some participants believed that if they gave some of their organs away, the process of resurrection would be hindered.

\section{(iv) Bio-ethical issues}

There are many ethical issues involved in organ donation. One major issue discussed by the participants was the choice of the recipient. There were two major questions related to this issue, one concerning the criteria of choice, the other related to who should make the final choice. Regarding the criteria of choice, all participants agreed that the person who is most in need of the organ should get the transplant. Some participants felt that young people and young mothers who have children should be given preference over older people. Others expressed the opinion that it should be on a first come first served basis, irrespective of age, sex, and urgency. This way, they claimed, there would be no abuses.

Another issue was whether the donor family has a right to decide to whom to give the organs. The official criteria do not make provisions for the donor family members to decide to donate an organ to somebody they know or even to a relative in need of a transplant. It was argued that whereas the cadaver is considered to be the property of the family, the same family cannot decide to give the organs to some other relative in need.

Participants were divided on the issue of the opt-out system. The few participants who were strongly in favour of organ donation were also in favour of the opt-out system, but others were more hesitant. Participants believed that the opt-out system could give rise to a situation where the organs of the dead person are removed when he or she would not have wanted to be an organ donor. Some considered the opt-out system as an infringement of one's human rights.

\section{(v) Medical issues}

Doctors are respected for their technical skills, trusted on a professional level but still open to criticism and suspicion as a professional class. Many feared that if they carried a donor card, doctors would not try to save their life if they are involved in an 
accident or if they are critically ill. They also feared that doctors will certify them dead, when in actual fact they are not, so that they can give the organs to friends and clients. McIntyre et al. (1987) similarly found that non-donors were afraid that if they carried a donor card, doctors could declare death prematurely for the purpose of obtaining their organs.

Some of the participants voiced their concern about the breakthroughs in science and technology. They were of the opinion that perhaps we should not be tampering with nature and that when our time is up on this earth, we should accept our faith and go with dignity.

\section{A further elaboration of the data: Metaphors of organ donation}

In the previous section, we briefly presented the data extracted from the focus group discussions classifying it into themes and then categories. In this section, we shall use the insight gained from this analysis in order to understand how the participants were trying to make sense of the concept of organ donation through the use of metaphors, how these metaphors were linked to social representations which participants had of the body, and how these social representations could be related to their attitudes towards the opt-out system. A similar study was carried out by Molony and Walker (2002) in Australia. These researchers found that the social representation of organ donation and transplantation could be best understood as a representational field organized around two diametrically 'opposed' images - the gift of life and the mechanistic removal and replacement of body parts. These images were also found in our study, however, as we shall see below, the results in the Maltese study indicated a more complex scenario involving more representations and interrelationships between them. In the rest of this section, we shall illustrate the way these metaphors were expressed by means of quotes taken from the focus group discussion transcripts.

Metaphors of organ donation resulting from the focus group discussions

The concept of organ donation was not so familiar among the general public when these focus groups were held. Therefore, participants in the focus groups had to express their ideas by comparing organ donation with more familiar concepts and phenomena. The words and metaphors used in the discussions were in themselves indications of the ideas they borrowed to understand this new concept. Table 2 presents the 12 metaphors and images which participants used to describe organ donation. The connotations associated with each metaphor explain in some more detail the nuances expressed by the participants using the metaphors.

(i) Giving a gift. The donation of organs was compared to giving a gift. It was believed that just like the decision to give a gift is completely in the hands of the giver, so should the decision whether or not to give the organs of the dead person, be taken by family of the dead person. Moreover, participants argued that as one chooses to whom to give gifts so should the family of the dead person have a right to decide to whom to give the organs of their loved one and that this decision should not be taken by the hospital authorities.

I think that, as in everything else, if your body belongs to you, then you have the right to determine who receives what. If there's a member of the family who needs an organ, then I should have the right to decide (Participant 30, male, 32 years). 
Table 2. Metaphors used to describe organ donation

\begin{tabular}{|c|c|}
\hline Metaphors & Connotations \\
\hline Giving a gift & $\begin{array}{l}\text { Donation of organs compared to giving } \\
\text { a gift. Just like the decision } \\
\text { to give a gift is in } \\
\text { the hands of the giver who } \\
\text { decides to whom to give a } \\
\text { gift, so should the decision to } \\
\text { give organs be in the hands } \\
\text { of donor or donor family who } \\
\text { should also decide to whom to } \\
\text { give organs }\end{array}$ \\
\hline Giving charity & $\begin{array}{l}\text { Just like a person can give } \\
\text { charity to people in need without } \\
\text { knowing the beneficiaries, so can a } \\
\text { person decide to donate organs without } \\
\text { knowing who will receive them }\end{array}$ \\
\hline Doing one's duty & $\begin{array}{l}\text { Donating organs is a duty similar } \\
\text { to, for example, taking care of } \\
\text { the environment }\end{array}$ \\
\hline Giving life & $\begin{array}{l}\text { God gives life. It is expected } \\
\text { for one to give back life } \\
\text { to others by donating organs }\end{array}$ \\
\hline Recycling of organs & $\begin{array}{l}\text { Just like engineers replace parts from } \\
\text { a machine into another to make } \\
\text { it work, so should doctors use } \\
\text { organs of dead people to cure } \\
\text { living ones in need of an } \\
\text { organ transplant }\end{array}$ \\
\hline Taking out an insurance policy & $\begin{array}{l}\text { People should carry donor cards. If } \\
\text { in need of an organ, those } \\
\text { who have card should be given } \\
\text { first preference when waiting for an } \\
\text { organ. It's like having an insurance policy }\end{array}$ \\
\hline Living on after dying & $\begin{array}{l}\text { Organ donation was seen as a } \\
\text { chance of keeping the organs and } \\
\text { the memories of the dead relative } \\
\text { alive in the recipient }\end{array}$ \\
\hline Desecrating the body & Dead body should be buried intact \\
\hline Dismembering the body & $\begin{array}{l}\text { Organ donation is seen as cutting } \\
\text { up a person }\end{array}$ \\
\hline Destroying a person's chance of an afterlife & $\begin{array}{l}\text { A person cannot go to heaven } \\
\text { or have a second life if } \\
\text { organs from the body are missing }\end{array}$ \\
\hline Destroying a person's identity & $\begin{array}{l}\text { Removing organs from the body is } \\
\text { destroying the identity of the person }\end{array}$ \\
\hline Playing God & $\begin{array}{l}\text { God creates the body and } \mathrm{He} \\
\text { has a plan for how long } \\
\text { the person should live. Organ donation } \\
\text { interferes with this plan }\end{array}$ \\
\hline
\end{tabular}


I don't agree that doctors can take the organs without permission first. I think it would be immoral to do so (Participant 4I, female, 25 years).

(ii) Giving charity. Organ donation was seen by many participants as giving charity. These participants believed that just like a person can give money or other possessions to people in need without knowing exactly who is going to benefit from their donations, so can a person decide to give his or her organs or those of a relative to patients who are in need of an organ transplant without knowing the names of the recipients.

Organ donation is the greatest act of charity you can think of (Participant I, female, 32 years).

I think organ donation is an act of brotherly love. You should love your neighbour as yourself and therefore be willing to help by giving your organs when you die (Participant 12, male, 25 years).

(iii) Doing one's duty. A number of participants believed that it is one's duty to donate organs after one's death. These participants believed that not doing so implies lack of certain principals and values just like, for example, not taking care of the environment.

Today, amongst the Maltese it might sound a bit hard at the beginning, but eventually this, yes, would become a duty (Participant 19, male, 56 years).

If I am alive God would want me to continue living, so I would not be able to give the organs to you. After death, however, it is my duty that I give away my organs. Otherwise I will not be practising what I believe in (Participant 19, male, 56 years).

(iv) Giving life. Most of the participants believed in God. These believed that as God gave them life, then it was 'expected' that after their death they help give 'a new life' to those who need an organ to survive. They believed that giving back life to a person who is on the point of dying is a heroic act.

I first heard about it in a film and it looked like a heroic act to me - to give an organ to save someone else's life. It's your chance to be great (Participant 32, female, 40 years).

(v) Recycling of organs. Some participants compared their body to a machine and organ donation to the recycling of spare parts. Just as engineers replace parts from a machine into another machine to make it work again, so should doctors use organs of dead people to cure living ones.

First of all I think recycling is a good thing - nothing is wasted. Secondly, it's all for a good cause. I don't like wasting anything - not even a piece of paper - imagine organs, which can be so useful to others. They can give them a new lease of life (Participant 7, female, 39 years).

(vi) Taking out an insurance policy. There were participants who believed that organs should be donated to those who are willing to donate their own organs and who are willing to carry a donor card. One participant believed that persons whose names appear on the organ donor register should be given preference over others, should they need an organ transplant.

I think that if your name is on the donor register there should be a policy that if a family member or friend need a kidney, they should have first preference. The doctor should not come and tell you, we are giving the kidney to $X$ or to $Y$ (Participant 4I, female, 25 years). 
(vii) Living on after dying. Some participants saw organ donation as a chance to keep the memory of the dead relative alive by actually having his or her organs living in another person. These people believed that the blow of loosing a close relative is made easier by knowing that the deceased has helped another person live on.

Let's suppose it's your son or daughter who dies, God forbid! The thought that a part of him or her is living in another person is a great consolation (Participant 22, female, 55 years).

When the girl Claudette from Dingli died I was very moved. I heard her mother saying that she wished she knew who received the organs because she feels her daughter is still alive. And she really impressed me (Participant 10, female, 49 years).

(viii) Desecrating the buman body. Some participants claimed that according to their religious believes it was wrong to cut up the body of the dead person after death. They believed that the body is sacred and should be respected by being buried intact.

That's why I asked you earlier about the position of the Church. Because the Church has always taught us to respect corpses. As a matter of fact there was a belief that you shouldn't touch a corpse or wash it before an hour passed over the person's death (Participant 30, male, 32 years).

You feel you are removing a part of the person you loved, taking it out. You feel you are committing an act of violence against the dead person, whose absence is already causing pain. How can you not bury him or her intact? (Participant 18, male, 32 years).

(ix) Dismembering the body. Others had this vivid picture of a dismembered body. They believed that when organs are taken from the dead body, the cadaver is left in a pitiful state with limbs and other organs lying about.

One of the reasons is the one mentioned by ' $X$ '. When my father died I thought about it, but the fear of them butchering him up and leaving him in an unsightly mess. . .! Probably I believe they would say why bother to tidy up the bits and pieces? I don't like it (Participant 39, female, 38 years).

(x) Destroying a person's chance of an afterlife. Many participants believed in an afterlife. They had different opinions of what forms the body would take but some argued that donating some organs of the dead person's body would destroy their chance of a second life.

As far as I know, St. Paul had said these words, 'Let the last trumpet play when the dead will rise without spoil'. Because, I start to think 'without spoil' - does it mean we shall be resurrected as we are now? So if they will take away my kidneys, will I be resurrected with them missing? Then I say, I do not want to think about these things (Participant 23, male, 67 years).

You die, and then the soul rejoins the body, and you go to heaven... That's the image we have. If you donate a kidney, then in the future you will have a kidney less (Participant 30, male, 32 years).

(xi) Destroying a person's identity. For some participants, the image of the body was intimately related to the person's identity. These participants believed that if doctors removed organs from the dead person, they were destroying the identity of the person and his or her uniqueness. They also voiced the concern about the identity of the recipients.

What I want to know is where science is leading us to, with all these transplants. The kidneys are all right. But the heart, the eyes, then we'll have the brain, so with your memory. Who will the 
person who receives the heart or the brain of the other be, himself or the other person? (Participant 35, male, 50 years).

(xii) Playing God. Some believed that God creates us and has a plan for us. No one, according to these participants, can take the role of God and decide when a person lives and when a person dies. In this context, organ donation was seen as 'playing God'.

No, if you're about to go, you should go, and that's it. You shouldn't try to prolong life. Your time is up. You shouldn't make it longer. From experience I know that those who received an organ kept coming in and out of hospital. Something always goes wrong (Participant 20, male, 40 years).

The metaphors discussed in this section are summarized in Table 2.

\section{Metaphors of organ donation and representations of the human body}

Table 3 describes how positive and negative views towards organ donation were rooted in the metaphors which the participants used to describe organ donation. These, in turn, were dependent on the images they had of the body, again expressed through metaphors. We have classified these images within three major social representations of the body: the body as belonging to God or a Higher Being, the body as a personal possession, and the body as self. The table also shows how attitudes towards the opt-out system were related to how metaphors on organ donation and representations of the body were interlinked. Table 3 is followed by a discussion which amplifies the information given in the table and the interrelationships between its different elements. We structure this discussion around the three representations of the body.

My body belongs to God. A very popular belief among participants was that one's body belonged to God or a Higher Being who created it. These participants claimed that their religion teaches that the body is a sacred temple where God dwells. God lives in each and every person. The body is created by God and belongs to God and hence everyone must take care of one's body both physically and spiritually.

Some of these people believed the above strongly and believed it literally. They therefore believed that the person had no right to decide to give away parts of the body both before and after death. Giving away organs, for these participants, meant destroying God's temple. It was an act of total disrespect towards the person and towards God. They argued that since it was God who created the person, only God could decide whether a person lived or died. If God wanted a person to live, He could perform a miracle and heal him or her. He did not need some other person's organs. The fact that a person was sick and was going to die meant that it was God's plan for him or her. Organ donation would mean interfering with God's plans and with nature. It was like playing God. Only God can give life. It was not the doctor's role to interfere with a person's predetermined life-span. They argued that doctors could help people get better with 'natural' means but if this were not possible then they should not meddle with nature. Organ donation was not considered 'normal medicine'. People holding these beliefs were against the opt-out system because they saw organ donation as going beyond the limits set by nature and, if practised, would create confusion and chaos.

Others believed the symbolic meaning of this claim. They believed that God created their bodies and hence their bodies were a gift from God. Because it was a gift, they believed that one must treasure it and could not do things with it which would go 


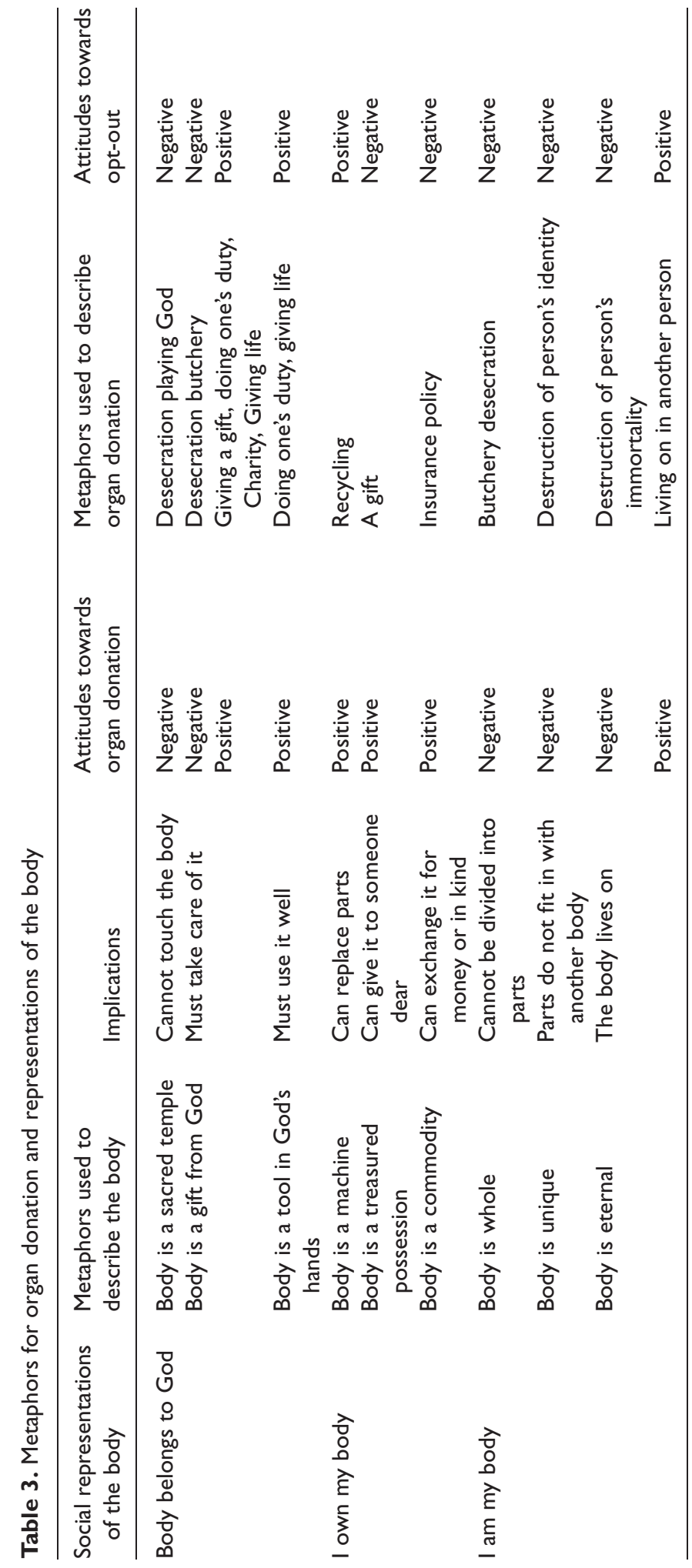


against God's wishes. Among these participants, there were those who saw organ donation as going against God's plan. These people saw organ donation as the desecration of the human body. Others, on the other hand, saw it in a positive light. These people claimed that if it is God's wish that a person helps others by donating one's organs then it was right to do so. It was an altruistic act, worthy of praise. It was like giving a gift of love. Some even saw it as a ticket to heaven. If one did such a noble act then God would reward him or her by accepting them in heaven.

Others still, saw their body as a tool in God's hands. These people saw themselves as channels or means by which and through which, God showed His love for humankind. Giving back life to a person who was at the point of death, was like performing a miracle. In this case, the donor was in a 'partnership' with God to save the person's life, an accomplice in this great act of love. These people saw the opt-out system as helping God save more lives.

I own my body. Another image of the body was that a person owned his or her body and therefore the person was responsible for it. He or she had to take care of it, keep it healthy, and enjoy it. If something went wrong, one had the duty to do all that is humanly possible to make it right. These people's relationships with their body were various. Some looked upon it as a machine - a complex mechanism which enabled the person to live and enjoy a healthy life. Others looked upon it in a more emotional way, more as a treasured possession, maybe their most treasured possession. They took care of it and shared it only with people they cared about or loved. Others still looked upon it as a commodity, something they could trade or negotiate.

Those who saw their bodies as a machine, looked upon the organs as spare parts. If a part was not functioning well, then it had to be repaired. If that failed it had to be replaced. Since organs cannot be manufactured, the only way of obtaining them was through the process of organ transplantation. To these people, recycling of body parts made sense and they looked upon organ donation and transplantation as a wise use of human physical resources. For them not doing so would be a shameful waste. These participants were generally in favour of the opt-out system.

Some people looked upon their bodies as a treasured possession, something which could not be given a financial value. It was like a gift given to you by someone you loved. You could not just give it away to anybody. Like a keepsake, you could give it to somebody who was very dear to you, somebody who you knew was going to take care of it and treasure it. These people, while accepting the idea of organ donation, could not accept that the donor or donor family had no right to decide to give these precious organs to relatives or dear friends in need. Moreover, some organs, like the eyes or the heart had a deeper significance for these people. Hence these people believed that it should be possible to choose the person to whom to give the organs and to be able to give one organ but not another if the person so desires. These participants also believed that donating one's organ should be a completely voluntary decision and were against the opt-out system.

Those who looked upon their body as a commodity, saw organs as having a value and an exchange value. They were for one's service but unlike those who looked upon their bodies as a machine, these participants believed that they could use their body to gain affection, acquire material possessions, or even sell their body for financial gain. Hence these people believed that organ donation should be rewarded either financially or in kind. Some of these people saw organ donation as an instrument or insurance policy. They believed that people who pledged their organs should be given preference if they 
or their families were ever in need of an organ. They also believed that organs should be stored in banks and that it should become possible to buy or exchange organs. These participants too were against the opt-out system. They believed that since they own their body, it is them and not the State who should decide what to do with it.

I am my body. Whereas some people had a dualistic view of the human being others did not distinguish between their physical bodies and their spiritual and psychological selves. They had a monistic view of the human person and did not separate the body from the spirit. The body was seen to be at the core of the identity of the individual. The body was the self. Almost all participants who had this representation of the body were against the opt-out system.

Some of these people looked upon the body as something whole, not made up of parts. They also saw the body as sacred and therefore could not be tampered with. Giving permission to doctors to take some organs was to them the same as allowing somebody to destroy a person, to destroy his or her identity and to tarnish his or her memory. This was seen as an insult to the sacredness of the human person and was an act of disrespect towards the person who died.

Some of these participants pointed out that persons were unique beings, one different from the other. Some people who had this view of the human person could not conceive of parts of one person being transferred into another. This created dissonance for them because a person was one whole being and not made up of parts. The body had one identity and each organ contributed to that identity. If the heart was contributing to the identity of a person, then when the heart was given to somebody else, they asked, who would the recipient be, a receptacle for the person's heart? What would happen to the identity of the donor and to that of the recipient?

Some people could not accept organ donation on the premise that it would interfere with the resurrection of the body after death. These people believed that the body lived on after it died. Because they viewed the body as something whole, they looked upon a body with missing organs as incomplete. Organ donation, they believed, would interfere with God's plan to resurrect the body. Some of these people believed that in the afterlife we would have the same body, with the difference that nothing could go wrong with it.

Whereas some people looked upon organ donation as destroying a person's chance of immortality, others looked upon it as a way of gaining a kind of immortality by living on in the other person. These believed that since a person's organs were still living in other people, then the person who had given his or her organs was not dead but was living in the recipients. These people were mostly in favour of opt-out.

\section{Discussion of results}

\section{The metaphors as homomorphisms}

We have already said that the explanatory power of the metaphor for the researcher studying how people view an issue derives from the way metaphors project familiar relationships on to the novel concepts. Amongst those who saw the body as belonging to God, two of the metaphors used to describe organ donation (Table 3) were desecration of the body and doing one's duty. It is not surprising that these participants differed in their attitudes towards the opt-out system. The metaphors used by these participants to describe the body give a more interesting picture. Some participants described the body as a sacred temple. Sacred temples are known to be inviolable, therefore it is natural that these participants would be against organ donation. At the 
other extreme, some participants saw their body as a tool in God's hands. These people therefore did not find it difficult to let go of their rights to this tool which did not belong to them, and were therefore in favour of organ donation. A more complex picture is presented by those who saw their body as a gift from God. Some participants reasoned that when somebody presents you with a gift, it is the norm not to give it to somebody else unless the second recipient is very dear. These participants therefore opposed the opt-out system. But some, perhaps thinking in terms of the parable of the talents as narrated in the New Testament (Matthew 25, verse 14), considered a gift from God to imply the responsibility to use the gift wisely. These people, although using the same metaphor to describe their body, were therefore in favour of the opt-out system.

This analysis of the metaphors and what meanings they project on to the concepts of the body and organ donation runs through Table 3 and helps to explain the different views held by the participants within the same social representation of the body. It is perhaps not surprising, for example, that amongst the category of participants who identified themselves with their body, most would be against both organ donation and the opt-out system. But a few of these participants described the body as eternal and organ donation as living on, in another person. These images suggested immortality and therefore led these particular participants to be in favour of both organ donation and the opt-out system.

\section{Implications for changing attitudes towards the opt-out system}

Changing the attitudes of people towards organ donation through public communication campaigns helps to increase the number of people who are willing to donate their organs after their death (Kopfman \& Smith, 1996; Lauri, 2008). But changing attitudes on such a complex issue as organ donation requires that the change agents understand the deeply rooted views held by the general public. People's beliefs towards organ donation are often shrouded in fears which are rooted in religious beliefs, death and the afterlife, pain, the way people look at their own body and many other complex issues. Often, change agents need to be guided by experts who advise them on how to address people's concerns. This is certainly an essential component in the process of preparing a communication campaign. However, ignoring the lay theories which the public creates to explain the issue in question could risk having a campaign talking at cross purposes with the public it is supposed to address. The theory of social representations seems to be the ideal theoretical tool to help avoid this from happening.

The Organ Donation Campaign held in Malta in 1996 was perhaps unique in that all its major components were designed around the social representations which were gleaned from the pre-campaign formative research. These included the content of the messages and the manner in which these messages were delivered. Extensive use was made of the very words uttered by the participants in the focus groups. Social representations were also the basis upon which the target population was segmented (Lauri, 2001, 2008).

As a result of the formative research carried out before the campaign, the researchers involved in its design decided not to try to change the public's strongly held social representations of the body, but instead to design campaign messages which would resonate with the metaphors associated with organ donation and exploit the fact that within every one of the three representations there was a nucleus of people who were in favour of the opt-out system. Moreover, the results of the national survey had indicated that while attitudes towards organ donation in general were very positive, the 
views towards the opt-out system were very mixed, even amongst those who were in favour of organ donation and who carried a donor card. It was therefore felt that a campaign coming out heavily in favour of the opt-out system might create resistance and the effort would backfire. The final decision on this matter was that the campaign should not try to push hard for the opt-out system.

\section{Conclusion}

In countries where many people on the waiting list for an organ transplant are dying, introducing legislation on the opt-out system might be the only way to save lives. But to minimize resistance to change, legislation must be accompanied by campaigns based on knowledge of the public's beliefs about organ donation. The lesson drawn from the results presented in this paper is that knowing how views towards organ donation are embedded within social representations of the body informs the campaign's messages to greater effect. The above discussion has shown that within all three major social representations of the body there were attitudes for and against the opt-out system. Campaign messages which try to change people's social representations of the body are doomed to failure, since these representations are deeply rooted. But messages designed to change attitudes towards the opt-out system within the same social representation of the body might be more effective. These messages should exploit and resonate with the different metaphors about organ donation expressed by persons whose views of the body are located within the three major social representations presented in Table 3 . This point of view can offer a radically different way of segmenting the target population in a public communication campaign and the designing of the appropriate message for each segment (Lauri, 2001, 2008).

Of course, the Maltese context presents a different scenario from the British one. The Maltese population is smaller, more homogeneous and greatly influenced by the Catholic Church. This sometimes had an important influence on the way the campaign proceeded. For example, all the pre-campaign research showed that one major misconception which many Maltese participants shared was that the Catholic Church was against organ donation. After a discussion between the researchers designing the campaign and the Church authorities, the Maltese bishops issued a pastoral letter in favour of organ donation. This immediately addressed most people's religious doubts about organ donation. Such an event may not be so easily available to a change agent in a country like the UK.

We believe that the findings presented in this paper can be relevant to policy makers, practitioners and academics in other countries. A cursory look at the on-line objections to Mr Brown's article, referred to in the introduction indicates that objections raised by the British readers are congruent with the attitudes of the participants in the focus groups carried out in Malta. It would not be surprising if images of the body would still feature prominently if similar research is carried out in the UK. However, it is very probable that, in the context of a country where attitudes to religion are so heterogeneous, this might not be the only or indeed the main factor, and any such analysis would have to include other important issues. Although specific details may be different, the use of social representations anchored in the metaphors people use to describe organ donation would still be a powerful tool in order to understand how people view organ donation and related issues such as the opt-out system.

In their article, 'Social marketing and communication in health promotion', Hastings and Haywood (1991) quote from the book To kill a mockingbird (Lee, 1960). The 
character Atticus Finch says 'you never really understand a person until you consider things from his point of view - until you climb into his skin and walk around in it'. This is what policy makers should do and the best way to do it is perhaps to understand the social representations related to the changes in policies being advocating.

\section{Acknowledgements}

I would like to thank the two anonymous referees who read the paper very carefully and whose suggestions helped me in no small way to write a better paper.

\section{References}

Augoustinos, M., \& Penny, S. L. (2001). Reconciliation: The genesis of a new social representation. Papers on Social Representations, 10, 4.1-4.18 http:/www.swp.uni-linz.ac.at/psr.htm.

Brown, G. (2008). Organ donations help us make a difference. The Telegraph. Retrieved January 13, 2008 from http://www.telegraph.co.uk/news/main.jhtml?xml=/news/2008/01/13/ norgans213.xml

Calvo, B. R., Blanca, M. J., \& de Frutos, M. A. (2002). Decision making about organ donation in the Andalusian population. Psicothema, 14(2), 300-309.

EU Consultation Document on Organ Donation (2006). Organ donation and transplantation policy options at EU level. Retrieved August 14, 2006 from http://ec.europa.eu/health/ ph_threats/humans_sunstance/oc_organs/consultation_paper.pdf

Farr, R. M., Trutkowski, C., \& Holzl, E. (1996). Public opinion, group discussion and theory of social representations (Research papers in psychology No. 9602). London: School of Economics.

Hastings, G., \& Haywood, A. (1991). Social marketing and communication in health promotion. Health Promotion International, 6(2), 135-145.

Jovchelovitch, S. (2007). Knowledge in context. Representations, community and culture. Sussex: Routledge.

Kopfman, J. E., \& Smith, S. W. (1996). Understanding the audiences of a health communication campaign: A discriminant analysis of potential organ donors based on intent to donate. Journal of Applied Communication Research, 24, 22-49.

Lauri, M. A. (2001). The social psychology of social marketing: Promoting organ donation in Malta. Unpublished PhD dissertation. London: University of London.

Lauri, M. A. (2006). Attitudes towards organ donation in the last decade. Malta Medical Journal, $18(4), 27-31$.

Lauri, M. A. (2008). Changing public opinion towards organ donation. A social psychological approach to social marketing. In L. O. Pietrieff \& R. V. Miller (Eds.), Public opinion research focus (pp.9-36). New York: Nova Science Publishers.

Lauri, M. A., \& Lauri, J. (2005). Social representations of organ donors and non-donors. Journal of Community and Applied Social Psychology, 15, 108-119.

Lee, H. (1960). To kill a mockingbird. New York: Penguin Bks.

McIntyre, P., Barnett, M. A., Harris, R. J., Shanteau, J., Skowronski, J., \& Klassen, M. (1987). Psychological factors influencing decisions to donate organs. Advances in Consumer Research, XIV, 331-334.

Molony, G., \& Walker, I. (2002). Talking about transplants: Social Representations and the dialectic, dilemmatic nature of organ donation and transplantation. British Journal of Social Psychology, 41, 299-320.

Morgan, S., \& Miller, J. K. (2002). Communications about gifts of life; the effect of knowledge, attitudes and altruism on behavioural intentions regarding organ donation. Journal of Applied Communications Research, 30(2), 163-178. 
Moscovici, S. (1961). La Psychanalyse: Son image et son public. Etude sur la representation sociale de la psychanalyse. Paris: Presses Universitaires de France.

Moscovici, S. (1973). Foreward. In C. Herzlich (Ed.), Health and illness: A social psychological analysis. London: Academic Press.

Moscovici, S. (1984). The phenomenon of social representations. In R. M. Farr \& S. Moscovici (Eds.), Social representations (pp.3-69). Cambridge: Cambridge University Press.

Perkins, K. (1987). The shortage of cadaveric donor organs for transplantation: Can psychology help? American Psychologist, 42(10), 921-930.

Sanner, M. (1994). Attitudes toward organ donation and transplantation. A model for understanding reactions to medical procedures after death. Social Science Medicine, 38(8), 1141-1152.

Wagner, W., Elejabarrieta, F., \& Lahnsteiner, I. (1995). How the sperm dominates the ovum objectification by metaphor in the social representation of conception. European Journal of Social Psychology, 25, 671-688.

Wagner, W., \& Hayes, N. (2005). Everyday discourse and common sense - the theory of social representations. Basingstoke: Palgrave-Macmillan.

Webster, P. (2008). Gordon Brown seeks to make everyone an organ donor - with opt-out. Retrieved January 14, 2008 from http://www.timesonline.co.uk/tol/news/politics/ article3182388.ece?pgnum $=1$

Wintor, P. (2008) Brown backs opt-out system to boost organ transplants. Retrieved January 14, 2008 from http://www.guardian.co.uk/politics/2008/jan/14/uk.publicservice/print

Received 13 February 2008; revised version received II November 2008

\section{Appendix}

\begin{tabular}{llcccc}
\hline & Group I & Group 2 & Group 3 & Group 4 & Group 5 \\
\hline No. of participants & 9 & 8 & 10 & 6 & 8 \\
Males & 4 & 1 & 7 & 1 & 5 \\
Females & 5 & 7 & 3 & 5 & 3 \\
Age range (years) & $19-50$ & $20-49$ & $20-67$ & $19-44$ & $19-43$ \\
Participant number & $1-9$ & $10-17$ & $18-27$ & $28-33$ & $34-41$ \\
\hline
\end{tabular}

